\title{
Model Regresi Logistik Terboboti Geografis pada Status Kemiskinan Kabupaten/Kota di Provinsi Sulawesi Selatan Tahun 2016
}

\author{
Sadriana Rustan*, Muhammad Arif Tiro, \& Muhammad Nadjib Bustan
}

Program Studi Statistika, Fakultas Matematika dan Ilmu Pengetahuan Alam, Universitas Negeri Makassar, Indonesia

Keywords: Logistic regression, kernel bisquare, GWLR and poverty.

\begin{abstract}
:
Logistic regression a analysis is used to determine the relationship between categorical response variables with one or more predictor variable assuming that the response is not influenced by geographical location (spatial data). One method of spatial analysis is Geographically Weighted Logistic Regression (GWLR). The GWLR model is a local form of logistic regression where the geographical location is considered and assumed to have a Bernoulli distribution. Estimating parameters of the RLTG model uses the Maximum Likelihood Estimation (MLE) method by giving different weights to different locations. The data were obtained from BPS publications, namely Data and Information on Poverty in South Sulawesi Province. This study aims to determine the factors that influence poverty status in South Sulawesi Province using a geographically weighted logistic regression model with kernel bisquare weighting function. The results showed that the explanatory variables that influence the status of poverty in the province of South Sulawesi were the percentage of the population not working and the percentage of common household toilet users.
\end{abstract}

\section{Pendahuluan}

Kemiskinan merupakan salah satu permasalahan mendasar yang menjadi pusat perhatian pemerintah semua negara di dunia, terutama bagi negara berkembang seperti Indonesia. Sulawesi Selatan merupakan provinsi yang memiliki jumlah penduduk miskin yang terbilang cukup tinggi di Indonesia. Provinsi Sulawesi Selatan memiliki 24 kabupaten/kota dan terdapat 3 kabupaten yang memiliki jumlah penduduk miskin paling tinggi yakni Kabupaten Pangkep sebesar 16,22\% dengan jumlah penduduk miskin 53,380 ribu jiwa, Jeneponto dengan persentase 15,40\% atau sekitar 55,350 ribu jiwa dan Toraja Utara sebesar 14,41\% dengan jumlah penduduk miskin 32,850 ribu jiwa (Sulselsatu, 2017). Selain 3 kabupaten tersebut, tidak menutup kemungkinan masih terdapat kabupaten/kota lain bisa mengalami permasalahan yang sama. Sebagai langkah awal dalam mengatasi masalah kemiskinan yaitu dengan mengetahui penyebab dari timbulnya kemiskinan. Salah satu metode analisis statistik yang sering digunakan untuk mengetahui faktor-faktor yang mempengaruhi digunakan analisis regresi logistik dengan peubah respon (Y) yang mengikuti distribusi bernoulli.

Pada umumnya regresi logistik digunakan pada data cross sectional yang tidak memperhatikan efek spasial. Sementara pada kasus kemiskinan, pengaruh ketetanggaan antar area tidak bisa dikesampingkan. Ada kemungkinan antar kabupaten saling mempengaruhi dimana kabupaten yang memiliki status kemiskinan atau memiliki penduduk miskin yang banyak maka daerah-daerah sekitarnya kemungkinan memiliki penduduk miskin yang besar juga. Hal ini sejalan dengan Hukum Geografi yang dikemukakan W. Tobler dalam Anselin (1988), yang menyatakan "everything is related to everything else, but near things are more related than distant this" artinya segala sesuatu saling

\footnotetext{
* Corresponding author.

E-mail address: sadriana.rustan@gmail.com
} 
berhubungan satu dengan yang lainnya, tetapi sesuatu yang lebih dekat akan lebih berpengaruh daripada sesuatu yang jauh. Hal tersebut diperkuat juga oleh fakta yang ditemukan oleh lembaga penelitian SMERU (2008) mengatakan bahwa kemiskinan mengandung dimensi spasial yakni lokasi masyarakat miskin tidaklah acak melainkan cenderung berkelompok pada suatu lokasi dengan karakteristik tertentu. Sebagai akibatnya kemiskinan di suatu wilayah akan memungkinkan mempengaruhi keadaan wilayah sekitarnya.

Salah satu solusi yang dapat dilakukan yaitu dengan memasukkan efek spasial ke dalam model regresi logistik. Dengan memasukkan efek spasial akan akan menghasilkan pendugaan yang lebih presisi dibandingkan tanpa memperhatikan efek spasial dalam hal ini karena spasial mampu menjelaskan tentang bagaimana fenomena georafis terdistribusi dan bagaimana perbandingan dengan fenomenafenomena yang lainnya. Spasial statistik merupakan analisis yang banyak digunakan untuk mendeskripsikan dan menganalisis pola spasial, yaitu bagaimana objekobjekgeografis terjadi dan berubah di suatu lokasi. Selain itu juga dapat membandingkan pola objek-objek yang ditemukan di lokasi lain. Serta analisis spasial mampu menghasilkan nilai ragam yang minimum.3

Dalam regresi spasial ada dua hal penting yang menjadi perhatian yaitu matriks pembobot dan pendekatan spasial yang digunakan. Dalam penelitian ini pendekatan yang digunakan adalah pendekatan titik dalam hal ini regresi terboboti geografis (RTG) karena RTG dapat digunakan untuk menganalisis data dari proses yang nonstasioner seperti pada kasus kemiskinan, serta mampu menghasilkan pendugaan yang berbeda pada tiap lokasi sehingga faktorfaktor yang berpengaruh pada tiap wilayah juga bisa berbeda-beda. Hal ini dapat berguna dalam mendapatkan informasi yang menarik dan penting pada tiap lokasi. Sedangkan matriks pembobot yang digunakan adalah pembobot kernel bisquare dengan alasan bahwa RTG hanya mempergunakan jarak dan jarak yang paling umum digunakan adalah jarak Kernel bisquare. Fungsi Kernel bisquare memiliki lebar jendela yang berbeda untuk setiap wilayah pengamatan. Hal ini disebabkan oleh kemampuan fungsi Kernel bisquare yang dapat menyesuaikan dengan kondisi titik-titik pengamatan.

Model regresi logistik yang memasukkan efek spasial ke dalam modelnya dalam hal ini pendekatan titik disebut dengan Regresi Logistik Terboboti Georafis (RLTG). Dengan metode ini akan diselidiki faktor-faktor yang mempengaruhi kemiskinan kabupaten/kota di Provinsi Sulawesi selatan.

\section{Metode Penelitian}

Jenis penelitian ini menggunakan metode pendekatan deskriptif dan kuantitatif, yaitu penelitian yang dilakukan dengan dengan mendeskripsikan data secara statistik deskriptif dan menganalisis data-data numerik (angka) dengan menggunakan metode statistika yaitu analisis Regresi Logistik Terboboti Geografis.

Data yang digunakan dalam penelitian ini adalah data kemiskinan kabupaten/kota di Provinsi Sulawesi Selatan tahun 2016 yang diperoleh dari BPS. Dalam penelitian ini digunakan data letak astronomi yang meliputi letak lintang dan letak bujur tiap kabupaten/kota di Provinsi Sulawesi Selatan sebagai pembobot geografis. Unit amatan yang digunakan dalam penelitian ini adalah sebanyak 24 kabupaten/kota di Provinsi Selawesi Selatan. Adapun peubah penjelas yang digunakan diperoleh dari BPS diantaranya adalah angka melek huruf (X1), penduduk yang tidak bekerja (X2), rumah tangga pengguna jamban bersama (X3), Pengeluaran per kapita untuk makanan (X4) dan persentase rumah tangga penerima program subsidi beras bantuan dari pemerintah (X5).

Teknik analisis data yang digunakan untuk mencapai tujuan pada penelitian ini adalah sebagai berikut:

(1) Melakukan ekplorasi data untuk mengetahui gambaran umum angka kemiskinan kabupaten/kota di Provinsi Sulawesi Selatan tahun 2016.

(2) Menentukan peubah-peubah penjelas yang digunakan dalam pendugaan model

(3) Melakukan pendugaan parameter model regresi logistik

(4) Melakukan uji signifikansi parameter model regresi logistik

(5) Menghitung nilai Odds ratio

(6) Melakukan uji kesesuaian model

(7) Menentukan nilai bandwidth24

(8) Menentukan jarak antar pusat kabupaten/kota dengan menggunakan jarak eucliden

(9) Menghitung matriks pembobot $\mathrm{Wi}(\mathrm{j})$ menggunakan fungsi pembobot kernel bisquare 
(10) Melakukan pendugaan parameter model RLTG

(11) Interpretasi

\section{Hasil dan Pembahasan}

\subsection{Analisis Deskriptif}

Penelitian ini menggunakan lima peubah penjelas yang mempengaruhi status kemiskinan di provinsi Sulawesi Selatan. Deskripsi dari kelima peubah penjelas yang digunakan dalam analisis data disajikan pada Tabel 1.

Tabel 1 Deskriptif Statistik Peubah Penjelas Kemiskinan di Provinsi Sulawesi Selatan

\begin{tabular}{lcccc}
\hline \multicolumn{1}{c}{ Peubah } & Min & Maks & Rerata & $\begin{array}{c}\text { Simpangan } \\
\text { baku }\end{array}$ \\
\hline Angka melek huruf $\left(\mathrm{X}_{1}\right)$ & 81,77 & 99,00 & 90,90 & 5,24 \\
Penduduk tidak bekerja $\left(\mathrm{X}_{2)}\right.$ & 16,21 & 59,38 & 41,44 & 11,14 \\
Pengguna jamban bersama & 42,72 & 92,61 & 68,36 & 15,71 \\
$\begin{array}{l}\text { Pengeluaran perkapita }\left(\mathrm{X}_{4}\right) \\
\text { Penerima bantuan beras }\left(\mathrm{X}_{5}\right)\end{array}$ & 48,48 & 63,04 & 56,46 & 3,43 \\
\hline
\end{tabular}

Rerata persentase angka melek huruf di Provinsi Sulawesi Selatan sebesar 90,90\% artinya lebih dari 90\% penduduk miskin usia 15-55 tahun di Sulawesi Selatan mampu membaca dan menulis. Adapun nilai simpangan baku yang relatif kecil yaitu 5,24\% artinya angka melek huruf cukup merata pada setiap kabupaten/kota di Provinsi Sulawesi Selatan. Persentase paling rendah untuk angka melek huruf di Provinsi Sulawesi Selatan dimiliki oleh Kabupaten Takalar dengan persentase sebesar 81,77\% sedangkan persentase paling tinggi dimiliki oleh Kota Makassar dengan persentase sebesar $99 \%$.

Rerata persentase penduduk tidak bekerja di Provinsi Sulawesi Selatan sebesar 41,44\% dengan simpangan baku yang cukup tinggi yaitu sebesar $11,14 \%$ artinya jumlah penduduk tidak bekerja di setiap Kabupaten/Kota di Provinsi Sulawesi Selatan tidak merata. Adapun persentase paling rendah untuk penduduk tidak bekerja di Provinsi Sulawesi Selatan dimiliki oleh kabupaten Tanah Toraja dengan persentase sebesar 16,21\% sedangkan persentase paling tinggi dimiliki oleh Kabupaten Barru dengan persentase sebesar 59,38\%.

Rerata rumah tangga pengguna jamban bersama di Provinsi Sulawesi Selatan sebesar 68,36\%. Nilai simpangan baku yang cukup besar yaitu $15,30 \%$ artinya Persentse rumah tangga pengguna jamban bersama tidak merata di setiap Kabupaten/Kota di Provinsi Sulawesi Selatan. Adapun persentase paling rendah untuk rumah tangga pengguna jamban bersama di Provinsi Sulawesi Selatan dimiliki oleh kabupaten Luwu dengan persentase sebesar 42,72\% sedangkan persentase paling tinggi dimiliki oleh Kabupaten Toraja Utara dengan persentase sebesar 92,61\%.

Rerata pengeluaran per kapita untuk makanan di Provinsi Sulawesi Selatan sebesar 56,46\% dengan simpangan baku sebesar 3,42\%. Adapun persentase paling rendah Pengeluaran per kapita untuk makanan di Provinsi Sulawesi Selatan dimiliki oleh Kota Makassar dengan persentase sebesar 48,48\% sedangkan persentase paling tinggi dimiliki oleh Kabupaten Jeneponto dengan persentase sebesar $63,04 \%$. Rerata rumah tangga penerima program subsidi beras bantuan pemerintah di Provinsi Sulawesi Selatan sebesar 51,66\% dengan simpangan baku yang cukup besar yakni $23,70 \%$ artinya rumah tangga penerima program subsidi beras bantuan pemerintah sangat tidak merata di setiap kabupaten/kota di Provinsi Sulawesi Selatan Adapun persentase paling rendah untuk rumah tangga penerima program 
subsidi beras bantuan pemerintah di Provinsi Sulawesi Selatan dimiliki oleh kabupaten Takalar dengan persentase sebesar 3,16\% sedangkan persentase paling tinggi dimiliki oleh Kota Palopo dengan persentase sebesar 96,00\%.

\subsection{Model Regresi logistik}

Model regresi logistik dapat digunakan untuk melihat hubungan antara status kemiskinan setiap kabupaten/kota di Provinsi Sulawesi Selatan dengan faktor-faktor yang berpengaruh terhadap status kemiskinan. Kemudian dilakukan pengujian secara serentak dan parsial untuk mengetahui peubah-peubah yang signifikan. Peubah respon yang digunakan adalah status kemiskinan $(\mathrm{Y})$ yang terdiri dari dua kategori yaitu miskin dan tidak miskin.

Model regresi logistik dibentuk menggunakan lima peubah penjelas secara bersamaan. Nilai statistik uji G yang dihasilkan pada model regresi logistik disajikan pada tabel 2.

Tabel 2 Uji Signifikansi Parameter Secara Serentak

\begin{tabular}{cccc}
\hline & $G^{2}$ & $d b$ & $\chi^{2}{ }_{(a d)}$ \\
\hline Model & 11,76 & 5 & 9,236 \\
\hline
\end{tabular}

Tabel 2 menunjukkan bahwa nilai statistik uji G yang dihasilkan pada model regresi logistik adalah 11,76 jika dibandingkan dengan nilai $\chi_{(0,1 ; 5)}^{2}=9,236$ maka nilai statistik uji G lebih besar daripada $\chi_{(0,1 ; 5)}^{2}$. Kesimpulan pengujian model regresi logistik secara serentak adalah tolak $\mathrm{H}_{0}$ (Hosmer dan Lemeshow, 2000), berarti minimal terdapat satu peubah penjelas yang berpengaruh terhadap kemiskinan di Provinsi Sulawesi Selatan. Dengan demikian pengujian dilanjutkan untuk mencari peubah mana yang berpengaruh signifikan secara parsial.

Penduga parameter dan hasil uji hipotesis secara parsial dari model regresi logistik ditunjukkan pada Tabel 3.

Tabel 3 Pendugaan Parameter Model Regresi Logistik

\begin{tabular}{ccccc}
\hline Parameter & Dugaan & Galat baku & P-value & $\begin{array}{c}\text { Odds } \\
\text { Ratio }\end{array}$ \\
\hline & $-20,69$ & 18,20 & 0,2557 & \\
$\mathrm{X}_{1}$ & 0,21 & 0,15 & 0,1549 & 1,24 \\
$\mathrm{X}_{2}$ & $-0,17$ & 0,08 & 0,0535 & 0,84 \\
$\mathrm{X}_{3}$ & $-0,08$ & 0,05 & 0,1799 & 0,92 \\
$\mathrm{X}_{4}$ & 0,23 & 0,21 & 0,2781 & 1,26 \\
$\mathrm{X}_{5}$ & $-0,02$ & 0,03 & 0,5176 & 0,97 \\
\hline
\end{tabular}

Tabel 3 menjelaskan bahwa peubah penduduk tidak bekerja $\left(\mathrm{X}_{2}\right)$ memiliki nilai p-value $=0,0535$ yang lebih kecil dari taraf kepercayaan $(\alpha)$ sebesar $10 \%$ maka dapat disimpulkan bahwa peubah penjelas yang berpengaruh nyata terhadap status kemiskinan di Provinsi Sulawesi Selatan adalah persentase penduduk Tidak bekerja $\left(\mathrm{X}_{2}\right)$.

Setelah dilakukan pengujian signifikansi parameter secara simultan dan parsial maka akan didapatkan model logit. Adapun model logit yang terbentuk dari peubah penjelas ditunjukkan pada persamaan berikut.

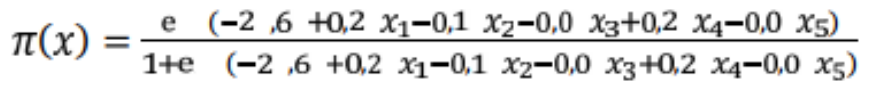


Berdasarkan nilai Odds ratio maka dapat dijelaskan bahwa hubungan antara persentase penduduk yang tidak bekerja $\left(\mathrm{X}_{2}\right)$ dengan status kemiskinan adalah negatif dengan nilai odds ratio sebesar 0,84 yang menjelaskan bahwa setiap kenaikan jumlah penduduk tidak bekerja suatu kabupaten/kota maka peluang p-value kabupaten tersebut untuk miskin sebesar 0,84 kali dibandingkan dengan kabupaten/kota yang tidak miskin.

\subsection{Uji Kesesuaian Model Regresi Logistik}

Uji kesesuaian model regresi logistik digunakan untuk mengetahui apakah model sesuai atau tidak terdapat perbedaan yang nyata antara hasil observasi dengan prediksi model, pada uji ini statistik uji yang digunakan adalah uji Hosmer dan Lemeshow seperti yang ditunjukkan pada Tabel 4.

Tabel 4 Hasil Uji Kesesuaian Model Regresi Logistik

\begin{tabular}{lcc}
\hline Chi-Square & $d f$ & p-value \\
\hline 0,44 & 3 & 0,9303 \\
\hline
\end{tabular}

Nilai Chi-Square pada Tabel 4 yang diperoleh sebesar 0,44 dan p-value = 0,9303. Dapat diartikan bahwa gagal tolak H0 karena p-value $>\alpha$ dengan $\alpha=10 \%$. Maka dapat disimpulkan bahwa model sesuai atau tidak terdapat perbedaan yang nyata antara observasi dengan prediksi model.

\subsection{Pembobot dan Bandwidth}

Model RLTG menggunakan pembobot berdasarkan letak geografis setiap kabupaten/kota. Langkah pertama yang dilakukan adalah dengan menentukan letak geograrafis (latitude dan longitude) tiap kabupaten/kota di Provinsi Sulawesi Selatan. Dalam suatu analisis penaksiran parameter di suatu titik $\left(u_{i}, v_{i}\right)$ akan lebih dipengaruhi oleh titiktitik yang dekat dengan lokasi $\left(u_{i}, v_{i}\right)$ dari pada yang lebih jauh. Oleh karena itu, dalam analisis RLTG terlebih dahulu menentukan matriks pembobot spasial menggunakan fungsi kernel bisquare, dengan rumus sebagai berikut:

$$
w_{i}\left(u_{i}, v_{i}\right)=\left\{\begin{array}{lcc}
\left(1-\left(d_{i} / h\right)^{2}\right)^{2}, & u & d_{i} \leq h \\
0 & u & d_{i}>h
\end{array}\right.
$$

dengan :

$$
d_{i}=\sqrt{\left(u_{i}-u_{j}\right)^{2}+\left(v_{i}-v_{j}\right)^{2}}
$$

Penentuan matriks pembobot dilakukan dengan menentukan letak geografis atau titik koordinat $(x, y)$ dari 24 kabupaten/kota di Provinsi Sulawesi Selatan, kemudian memilih bandwidth (h) optimum. Penentuan bandwidth (h) optimum dilakukan dengan menggunakan metode Cross Validation (CV). Berikutnya memilih bandwidth untuk setiap kabupaten/kota dengan fungsi Kernel bisquare. Perhitungan bandwidth didasarkan pada jarak suatu wilayah dengan tetangga terdekat yang memberikan pengaruh terhadap wilayah tersebut.

Berdasarkan Tabel 5 nilai bandwidth dengan fungsi Kernel bisquare untuk Provinsi Sulawesi Selatan diperoleh dari hasil simulasi ke-12 adalah 0.8779194 dengan nilai $\mathrm{CV}=5,076226$. 
Tabel 5 Nilai Bandwidth dan CV

\begin{tabular}{ccc}
\hline Simulasi & Bandwidth & CV \\
\hline 1 & 0,381966 & 34,70466 \\
2 & 0,618034 & 7,715911 \\
3 & 0,763932 & 5,519684 \\
$\cdot$ & $\cdot$ & $\cdot$ \\
$\cdot$ & $\cdot$ & $\cdot$ \\
. & $\cdot$ & $\cdot$ \\
12 & 0,8779601 & 5,076226 \\
13 & 0,8778787 & 5,076226 \\
14 & 0,8779194 & 5,076226 \\
\hline
\end{tabular}

\subsection{Model Regresi Logistik Terboboti Geografis}

Model regresi logistik terboboti geografis adalah merupakan model lokal untuk data yang memiliki efek keragaman spasial. Penduga parameter model RLTG diperoleh dengan memasukkan pembobot untuk setiap wilayah pengamatan (Saefuddin et al.,2013), perhitungan ini diselesaikan menggunakan software R Studio. Pendugaan parameter model RLTG diperoleh dengan memasukkan pembobot spasial dalam perhitungannya dengan menggunakan metode MLE.

Tabel 6 Penduga Parameter Model RLTG dengan Fungsi Pembobot Kernel bisquare

\begin{tabular}{cccccc}
\hline Parameter & Minimum & Kuartil 1 & Median & Kuartil3 & Maksimum \\
\hline intercept & $-19,59$ & $-11,35$ & 8,72 & 19,03 & 169,35 \\
$X_{1}$ & $-0,45$ & 0,11 & 0,23 & 0,27 & 0.33 \\
$X_{2}$ & $-0,91$ & $-0,41$ & $-0,23$ & $-0,04$ & $-0,01$ \\
$X_{3}$ & $-0,19$ & $-0,15$ & $-0,13$ & $-0,12$ & $-0,09$ \\
$X_{4}$ & $-1,20$ & $-0,25$ & 0,04 & 0,06 & 0,19 \\
$X_{5}$ & $-0,23$ & $-0,03$ & $-0,022$ & $-0,08$ & 0,011 \\
\hline
\end{tabular}

Berdasarkan Tabel 6 diperoleh estimasi parameter model RLTG dengan fungsi pembobot Kernel bisquare, dimana untuk melihat penduga parameter yang signifikan yaitu dengan melihat interval dari nilai minimum dan nilai maksimum setiap peubah. Apabila nilai interval antara nilai minimum dan nilai maksimum memuat 0 (nol), maka dapat disimpulkan bahwa penduga parameter $\beta$ tidak signifikan, sebaliknya jika nilai interval antara nilai minimum dan nilai maksimum tidak memuat 0 (nol), maka dapat disimpulkan bahwa penduga parameter $\beta$ dinyatakan signifikan. Hal ini dapat dilihat pada Tabel 6 bahwa peubah penjelas X2 berada pada interval antara nilai minimum sebesar -0.91 dan nilai maksimum sebesar -0,01, dimana pada interval kepercayaannya tidak memuat 0 (nol) maka dapat disimpulkan bahwa parameter $\beta_{2} \neq 0$ yang artinya signifikan. Selanjutnya, untuk parameter peubah X3 berada pada interval antara nilai minimum sebesar $-0,19$ dan nilai maksimum sebesar $-0,09$, dimana pada interval kepercayaannya tidak memuat 0 (nol) maka dapat disimpulkan bahwa parameter $\beta_{3} \neq 0$ yang artinya signifikan.

Sehingga dapat disimpulkan bahwa estimasi parameter model RLTG dengan menggunakan fungsi pembobot Kernel bisquare yang signifikan adalah parameter $\beta_{2}$ dan $\beta_{3}$, sedangkan yang tidak signifikan adalah parameter $\beta_{0}, \beta_{1}, \beta_{4}$ dan $\beta_{5}$. 


\section{Kesimpulan}

Dari hasil penelitian yang telah dilakukan, maka dapat disimpulkan bahwa:

1) Penentuan Estimasi parameter $(\beta)$ regresi logistik dan regresi logistik terboboti geografis dilakukan dengan mencari nilai $\beta$ yang memaksimalkan fungsi likelihood yaitu melalui log likelihood. Nilai $\beta$ tersebut diperoleh melalui metode Newton-Raphson.

2) Dari hasil analisis regresi logistik maka diperoleh peubah yang berpengaruh signifikan terhadap status kemiskinan kabupaten/kota di Provinsi Sulawesi Selatan yaitu peubah tidak bekerja $\left(\mathrm{X}_{2}\right)$ dengan nilai odds ratio sebesar 0,84 yang berarti bahwa setiap kenaikan jumlah penduduk tidak bekerja di suatu kabupaten/kota maka peluang suatu kabupaten untuk miskin sebesar 0,84 kali dibandingkan dengan kabupaten/kota yang tidak miskin.

3) Dari hasil analisis regresi logistik terboboti geografis diperoleh beberapa peubah yang berpengaruh signifikan terhadap status kemiskinan kabupaten/kota di Provinsi Sulawesi Selatan yaitu peubah tidak bekerja $\left(\mathrm{X}_{2}\right)$ dan rumah tangga pengguna jamban bersama $\left(\mathrm{X}_{3}\right)$

\section{References}

Anselin, L. (1988). Spatial Econometrics. Dallas: School of Social Science.

Hosmer, D. W., \& Lemeshow, S. (2000). Applied Logistic Regression (Second Edition). New York: John. Wiley \& Sond, INC.

Saefuddin, A., Saepuddin, D., \& Kusumaningrum, D. (2013). Geographically Weighted Poisson Regression (GWPR) for analyzing the malnutrition data in Java-Indonesia. Bogor Agricultural University, Department of Statistics, Bogor, Indonesia.

SMERU (2008). Menuju Kebijakan Permasyarakatan Miskin Melalui pendidikan.

Sulsel satu. (2016). Tingkat kemiskinan di Provinsi Sulawesi Selatan, [online], http://www.sulselsatu.com (diakses 24 Maret 2018) 